\title{
Pengaruh Level Glutathione terhadap Kualitas Post-Thawing Semen Kambing Peranakan Etawah
}

\section{Nurcholidah Solihati*, Soeparna, Siti Darodjah Rasad, Rangga Setiawan, Annisaa Yusrina}

\author{
Fakultas Peternakan, Universitas Padjadjaran \\ J1. Raya Bandung Sumedang Km 21, Jatinangor Sumedang \\ *Email korespondensi: nurcholidah@unpad.ac.id
}

(Diterima 17-01-2020; disetujui 12-05-2020)

\begin{abstract}
ABSTRAK
Glutathione merupakan antioksidan yang berfungsi melindungi sel dari kerusakan akibat oksigen reaktif (ROS) sehingga dapat mencegah reaksi peroksidasi lipid. Penggunaan glutathione dalam pengencer harus sesuai supaya tidak menimbulkan efek negatif. Penelitian ini bertujuan untuk mengetahui pengaruh level glutathione terhadap kualitas semen kambing Peranakan Etawah post thawing dan mengetahui level glutathione yang menghasilkan kualitas semen yang terbaik. Metode penelitian yang digunakan adalah percobaan laboratorium. Penelitian ini mengunakan rancangan acak kelompok dengan lima kelompok kambing dan lima level glutathione $(0,4,6,8$ dan $10 \mathrm{mM})$, setiap perlakuan diulang dua kali. Semen ditampung dengan vagina buatan dan dievaluasi secara makroskopis dan mikroskopis, selanjutnya dilakukan pengolahan menjadi semen beku Data dianalisis dengan analisis ragam dan perbedaan antar perlakuan diuji dengan uji lanjut Duncan. Parameter yang diamati adalah kualitas semen post-thawing meliputi motilitas, abnormalitas, membran plasma utuh dan tudung akrosom utuh (TAU). Hasil penelitian menunjukkan bahwa perlakuan level glutathione berpengaruh nyata $(\mathrm{p}<0,05)$ terhadap kualitas semen post-thawing. Hasil uji Duncan menunjukkan bahwa motilitas, TAU dari perlakuan level glutathione $6 \mathrm{mM}$ dan $8 \mathrm{mM}$ tidak berbeda nyata, namun MPU hasil $8 \mathrm{mM}$ nyata lebih tinggi dari level lainnya. Disimpulkan bahwa level glutathione berpengaruh terhadap kualitas semen post-thawing, dan level glutathione $8 \mathrm{mM}$ menghasilkan kualitas semen yang terbaik.
\end{abstract}

Kata kunci: glutathione, kualitas semen, post-thawing, kambing peranakan etawah

\begin{abstract}
Glutathione is an antioxidant that functions to protect cells from damage caused by reactive oxygen (ROS) so that it can prevent lipid peroxidation reactions. The use of glutathione in diluents must be suitable so as not to cause negative effects The aim of the research were to knew the effect of glutathione level on semen quality of Etawah Crossbreed goat and to knew the level of gluthathion that produce the best post-thawed semen quality. This research used grouped randomized design with five groups of goat and five glutathione levels $(0,4,6,8$ and $10 \mathrm{mM})$, every treatment was repeated for twice. Semen was collected with artificial vagina and was evaluated as macroskopic and misroskopic, then were being processed as frozen semen. Data was analyzed with analysis of varians and differences between treatments were analyzed using Duncan test. Parameter was observed is pot-thawed semen quality consist of motility, abnormality, intact plasma membrane (IPM) and intact acrosome cup (IAC). Result showed that treatment of glutathione level significantly $(\mathrm{p}<0.05)$ affect on post-thawed semen quality. Duncant test showed that motility and IAC from treatment glutathione of $6 \mathrm{mM}$ and $8 \mathrm{mM}$ were not significant, nevertheless IPM from treatment $8 \mathrm{mM}$ glutathione significantly higher than other levels. It is concluded that glutathione level significantly affect on post-thawed semen quality, and $8 \mathrm{mM}$ glutathione level resulted the best quality.
\end{abstract}

Keywords: glutathione, semen quality, post-thawed, etawah crossbreed goat 


\section{PENDAHULUAN}

Kambing peranakan etawah (PE) merupakan salah satu komoditas ternak yang berkembang di Indonesia sebagai penghasil daging dan susu, telah beradaptasi baik dengan kondisi tropis basah di Indonesia. Kambing ini merupakan hasil persilangan antara kambing etawah dari India dengan kambing kacang (lokal).

Salah satu upaya untuk meningkatkan populasi kambing PE yaitu dengan melakukan inseminasi buatan (IB), namun teknologi ini tergantung pada kualitas semen pejantan. Aplikasi IB akan lebih efisien dengan menggunakan semen beku, namun kualitas semen akan mengalami penurunan setelah mengalami proses pembekuan. Hal ini mendorong usaha untuk mencari suatu bahan yang dapat meminimalisir penurunan kualitas semen, salah satunya dengan menambahkan antioksidan.

Antioksidan merupakan senyawa nukleofilik atau yang memiliki kemampuan menekan reaksi radikal bebas. Antioksidan yang telah banyak digunakan salah satunya adalah glutathione. Glutathione merupakan salah satu antioksidan golongan antioksigen yang berfungsi melindungi sel dari kerusakan akibat sifat toksik yang disebabkan oleh oksigen reaktif (ROS) (Lenzi et al., 2002) dan mampu menetralisir kerja radikal bebas sehingga mencegah terjadinya reaksi peroksidasi lipid (Suryohudoyo, 2000). Glutathione berperan mencegah terjadinya peroksidasi lipida membran plasma sperma selama proses pembekuan semen, sehingga dapat meningkatkan motilitas dan integritas akrosom post-thawing (Holt, 2000).

Beberapa peneliti telah melaporkan penggunaan glutathione pada semen ternak, diantaranya pada domba lokal telah dilaporkan bahwa level $5 \mathrm{mM}$ memberikan kualitas semen yang terbaik (Solihati et al., 2018). Penambahan 5 $\mathrm{mM}$ glutathione ke dalam pengencer menghasilkan motilitas sperma semen beku kambing lebih tinggi $(53,64 \%)$ dibandingkan dengan penambahan 2 $\mathrm{mM}(48,9 \%)$ dan tanpa penambahan glutathione (47,8\%) (Sinha et al., 1996). Penambahan $5 \mathrm{mM}$ glutathione di dalam pengencer dapat meningkatkan motilitas sperma semen beku sapi dari 30,35\% menjadi 33,1\% (Slaweta \& Laskowska, 1987). Penggunaan glutathione dalam media pengencer diharapkan dapat mengurangi timbulnya radikal bebas yang dapat merusak membran plasma, akan tetapi penggunaan glutathione harus sesuai supaya tidak menimbulkan efek negatif. Berdasarkan hal tersebut penulis melakukan penelitian mengenai pengaruh level glutathione terhadap kualitas semen post-thawing kambing PE.

Tujuan penelitian ini untuk mengetahui pengaruh level glutathione terhadap kualitas postthawing semen kambing PE dan mengetahui level glutathione yang menghasilkan kualitas semen kambing PE terbaik.

\section{MATERI DAN METODE}

\section{Materi Penelitian}

Objek penelitian yang digunakan adalah semen kambing PE jantan umur 2 tahun sebanyak lima ekor. Kambing dibagi dalam 5 kelompok, masing-masing kambing ditampung sebanyak dua kali yang merupakan jumlah ulangan, sehingga diperoleh 10 ejakulat semen. Bahan yang digunakan adalah larutan Tris, $\mathrm{NaCl} 3 \%, \mathrm{NaCl}$ fisiologis, pewarna eosin, tris aminomethane, fruktosa, aquabidestilata, kuning telur, penicillin, streptomycin, gliserol, glutathione, nitrogen cair, dan polyvinyl alcohol. Peralatan yang digunakan diantaranya mikroskop, object glass, cover glass, kertas lakmus, bunsen, counter, pipet haemocytometer, kamar hitung neubauer, tabung reaksi, pipet, labu erlenmeyer, gelas ukur, straw, styrofoam, rak besi, corong plastik, goblet, canister, container, dan pinset.

\section{Metode Penelitian}

Metode Penelitian yang digunakan adalah percobaan laboratorium dengan menggunakan lima perlakuan level glutathione dan lima kelompok kambing. Kelima perlakuan terdiri dari: P0 (Semen + Pengencer tanpa penambahan glutathione), P1 (Semen + Pengencer $+4 \mathrm{mM}$ glutathione), $\mathrm{P} 2$ (Semen + Pengencer + $6 \mathrm{mM}$ glutathione), P3 (Semen + Pengencer $+8 \mathrm{mM}$ glutathione), dan P4 (Semen + Pengencer $+10 \mathrm{mM}$ glutathione)

\section{Prosedur Penelitian}

Penampungan semen dilakukan dengan metode vagina buatan. Evaluasi terhadap semen segar dilakukan secara makroskopis dan mikroskopis. Pemeriksaan makroskopis meliputi volume, bau semen, $\mathrm{pH}$ semen, warna semen, konsistensi atau derajat kekentalan. Pemeriksaan mikroskopis meliputi gerakan massa sperma, konsentrasi sperma total, motilitas, dan abnormalitas sperma.

\section{Pengenceran dan Pembekuan Semen}

Semen segar yang telah dievaluasi selanjutnya akan dilakukan pengenceran terlebih dahulu sebelum memasuki tahap pembekuan. 
Pengencer yang digunakan adalah tris kuning telur. Gliserol diberikan sebanyak 6\%. Pengencer yang telah dibuat dibagi menjadi lima untuk masingmasing perlakuan. Pengencer pertama tidak diberi tambahan antioksidan, sedangkan pengencer kedua, ketiga, keempat dan kelima masing-masing diberi tambahan glutahione sebanyak $4 \mathrm{mM}, 6$ $\mathrm{mM}, 8 \mathrm{mM}$, dan10 mM.

\section{Pengenceran Semen}

Penambahan pengencer dilakukan sedikit demi sedikit kedalam tabung semen melalui dinding tabung menggunakan pipet. Kemudian diaduk secara perlahan hingga homogen.

\section{Pengemasan Semen (Filling dan Sealing)}

Semen yang telah diencerkan kemudian dikemas menggunakan straw. Kemasan semen yang digunakan yaitu model IMV perancis dengan volume setiap straw sebesar 0,25 $\mathrm{ml}$. Pengemasan dilakukan pada suhu lingkungan $5^{\circ} \mathrm{C}$. Bagian straw yang memiliki sumbat disambungkan dengan selang plastik penghisap, sedangkan ujung selang plastik lain disambungkan dengan pompa penghisap. Semen dituangkan ke dalam cawan untuk pengisian straw, kemudian hidupkan pompa penghisap agar semen masuk kedalam straw. Ujung straw yang telah berisi semen ditutup dengan tepung polyvinyl alcohol.

\section{Equilibrasi dan Freezing}

Semen cair yang telah dikemas disimpan kedalam lemari es dengan temperatur $5^{\circ} \mathrm{C}$ selama 4 jam. Hal ini dilakukan agar spermatozoa dapat menyesuaikan dengan pengencer sebelum proses pembekuan. Straw disimpan di dalam Goblet, lalu dimasukan kedalam canister dan diuapkan di atas permukaan Nitrogen cair di dalam container pada suhu $-80^{\circ} \mathrm{C}$ sampai dengan $-100^{\circ} \mathrm{C}$ selama 7 menit (pre freezing). Gas nitrogen akan menguapi straw dengan jarak antara straw dan permukaan cairan sekitar 3-5 cm. Setelah pre freezing selesai, dilanjutkan proses pembekuan di dalam nitrogen cair dengan suhu mencapai $-196^{\circ} \mathrm{C}$.

\section{Pencairan Kembali Semen Beku (Thawing)}

Semen yang telah dibekukan, dicairkan kembali untuk mengevaluasi kualitas semen setelah dibekukan. Proses thawing dilakukan dengan cara memasukkan ke dalam bejana berisi air dengan temperature $37^{\circ} \mathrm{C}$ selama 35 detik. Peubah yang diamati meliputi motilitas, abnormalitas, membran plasma utuh dan tudung akrosom utuh.

\section{Rancangan Percobaan dan Analisis Data}

Penelitian dilakukan dengan menggunakan Rancangan Acak Kelompok dengan lima kelompok kambing dan lima perlakuan level glutathione. Setiap kelompok kambing ditampung semennya sebanyak dua kali, sehingga jumlah ulangan yaitu sebanyak dua kali. Data dianalisis menggunakan analisis varian dan perbedaan antar perlakuan diuji dengan uji lanjut berganda Duncan.

\section{HASIL DAN PEMBAHASAN}

\section{Kualitas Semen Segar Kambing PE}

Semen segar dievaluasi untuk mengetahui kualitas sebelum dilakukan pengenceran dan pembekuan. Syarat semen segar yang akan dibekukan yaitu minimal persentase motilitas $70 \%$, konsentrasi $2 \times 10^{9} \mathrm{sel} / \mathrm{ml}$, gerakan massa ++/+++, persentase hidup minimal $80 \%$ dan persentase abnormal tidak lebih dari 15\% (Tambing et al., 2000). Hasil pemeriksaan semen segar kambing PE dapat dilihat pada Tabel 1.

Berdasarkan Tabel 1 dapat dilihat bahwa kambing PE memiliki rata-rata volume semen $0,68 \pm 0,20 \mathrm{ml} /$ ejakulat. Menurut Heriyanta et al. (2013), volume semen kambing PE umur 1-2 tahun memiliki rata-rata volume sebesar $2,2 \pm 0,5 \%$, sedangkan menurut Hastono et al. (2013), volume kambing PE yaitu mencapai 0,86 $\pm 0,40 \mathrm{ml} /$ ejakulat. Kambing ke-2 dan ke-5 memiliki volume semen terendah sebesar $0,5 \mathrm{ml}$ per ejakulat, sedangkan volume semen yang paling tinggi sebesar 1,1 ml/ejakulat pada kambing ke-3. Kambing yang memiliki volume semen rendah dapat disebabkan oleh kualitas pakan yang kurang baik, umur dan genetik sesuai dengan pernyataan Feradis (2010) bahwa volume semen per ejakulat dipengaruhi oleh umur, kualitas pakan, frekuensi penampungan, bangsa dan berbagai faktor lainnya.

Warna semen segar yang dihasilkan yaitu normal atau krem, sedangkan konsistensi pada semen segar dari lima kelompok yaitu kental. Hal ini sesuai dengan pernyataan Hastono et al. (2013); Suyadi et al. (2015) bahwa semen kambing berkualitas baik memiliki warna krem dengan konsistensi yang kental. Konsistensi semen dipengaruhi oleh perbandingan antara spermatozoa dengan plasma semen. Warna, konsistensi dan konsentrasi spermatozoa mempunyai hubungan yang sangat erat satu dengan yang lain. Semen yang semakin encer maka konsentrasi semakin rendah dan warna akan semakin pucat. 
Tabel 1. Kualitas Segar Semen Kambing Peranakan Etawah

\begin{tabular}{|c|c|c|c|c|c|c|c|c|c|c|}
\hline \multirow[b]{2}{*}{ Kel } & \multicolumn{10}{|c|}{ Parameter } \\
\hline & $\begin{array}{l}\text { Volume } \\
\text { (ml) }\end{array}$ & $\mathrm{pH}$ & Warna & $\begin{array}{l}\text { Visko } \\
\text {-sitas }\end{array}$ & GM & $\begin{array}{c}\mathrm{KT} \\
\left(10^{7} \mathrm{sel} / \mathrm{ml}\right)\end{array}$ & $\begin{array}{c}\text { Motilitas } \\
(\%)\end{array}$ & $\begin{array}{l}\text { Abnor- } \\
\text { malitas } \\
(\%)\end{array}$ & $\begin{array}{l}\text { MPU } \\
(\%)\end{array}$ & $\begin{array}{l}\text { TAU } \\
(\%)\end{array}$ \\
\hline $\mathrm{K} 1$ & $0,65 \pm 0,07$ & $6,60 \pm 0,14$ & krem & Kental & $(+++)$ & $242,0 \pm 19,80$ & $75,85 \pm 5,02$ & $1,50 \pm 0,00$ & $83,50 \pm 4,24$ & $85,00 \pm 6,36$ \\
\hline $\mathrm{K} 2$ & $0,50 \pm 0,00$ & $6,75 \pm 0,07$ & krem & Kental & $(+++)$ & $319,00 \pm 9,90$ & $72,60 \pm 0,85$ & $2,00 \pm 0,00$ & $87,00 \pm 1,41$ & $84,50 \pm 2,12$ \\
\hline $\mathrm{K} 3$ & $1,00 \pm 0,14$ & $6,25 \pm 0,35$ & krem & Kental & $(+++)$ & $406,00 \pm 2,83$ & $75,15 \pm 0,21$ & $1,50 \pm 0,71$ & $84,50 \pm 0,00$ & $83,00 \pm 0,71$ \\
\hline $\mathrm{K} 4$ & $0,70 \pm 0,14$ & $6,35 \pm 0,21$ & krem & Kental & $(+++)$ & $234,50 \pm 12,02$ & $82,55 \pm 3,75$ & $1,75 \pm 0,35$ & $88,00 \pm 1,41$ & $83,25 \pm 1,77$ \\
\hline $\mathrm{K} 5$ & $0,55 \pm 0,07$ & $6,55 \pm 0,07$ & krem & Kental & $(+++)$ & $404,50 \pm 10,61$ & $79,30 \pm 2,97$ & $1,50 \pm 0,00$ & $84,50 \pm 4,95$ & $87,00 \pm 2,12$ \\
\hline $\begin{array}{l}\text { Rata } \\
\text { - rata }\end{array}$ & $0,68 \pm 0,20$ & $6,50 \pm 0,24$ & krem & kental & $(+++)$ & $321,2 \pm 79,31$ & $77,09 \pm 4,34$ & $1,65 \pm 0,34$ & $85,5 \pm 2,9$ & $84,55 \pm 2,86$ \\
\hline
\end{tabular}

Keterangan :

K1, K2, K3, K4, K5: Kambing 1 s.d. 5

GM : Gerakan Massa MPU : Membran Plasma Utuh

KT : Konsentrasi Total TAU : Tudung Akrosom Utuh

Rata-rata derajat keasaman $(\mathrm{pH})$ semen segar dari lima kambing PE dengan masingmasing dua kali penampungan yaitu 6,50 $\pm 0,24$. Berdasarkan hasil penelitian Tambing et al. (2000), pH semen segar kambing PE sekitar $7,0 \pm 0,21$. Hasil pengamatan menunjukkan bahwa derajat keasaman pada kelima kambing tersebut normal. Derajat keasaman pada semen yang normal yaitu netral sekitar 6,8 sedangkan untuk $\mathrm{pH}$ semen yang mencapai 7,0 atau lebih dikarenakan penampungan semen terlalu sering, proses ejakulasi yang tidak sempurna, dan akibat kondisi-kondisi patologik (Toelihere, 1993).

Hasil pemeriksaan secara mikroskopis pada semen segar kambing PE menunjukkan hasil yang cukup baik. Gerakan massa sperma dari lima kelompok kambing PE yaitu berkisar antara (++) sampai dengan (+++), hasil tersebut menunjukkan bahwa saat pengamatan, semen memiliki pergerakan yang cepat dan membentuk awan hitam. Hal ini sesuai dengan Tambing, et al. (2000) bahwa gerakan massa pada kambing PE yaitu (+++). Menurut Toelihere (1993), semen dengan skor gerakan massa $(++) /(+++)$ saja yang layak untuk diproses, baik diencerkan maupun dibekukan.

Menurut Heriyanta et al. (2013), konsentrasi spermatozoa kambing PE umur 1-2 tahun yaitu $2265,25 \pm 177,8$ juta $\mathrm{sel} / \mathrm{ml}$ dan motilitasnya sebesar $68,5 \pm 7,9 \%$, sedangkan menurut Hastono et al. (2013), konsentrasi sperma total semen segar kambing PE yaitu $3100 \pm 0,5$ juta sel $/ \mathrm{ml}$. Hasil penelitian ini menunjukkan rata-rata konsentrasi sperma total yang dihasilkan 3212 $\pm 793,1$ juta sel/ml. Rata- rata motilitas semen segar kambing PE yaitu sebesar 77,09 $\pm 4,34 \%$. Hasil pengamatan konsentrasi sperma total dan motilitas tersebut menunjukkan bahwa semen kelima kambing memiliki kualitas yang cukup baik.

Rata-rata persentase abnormalitas semen segar kambing PE yang dihasilkan cukup rendah yaitu $1,65 \pm 0,34 \%$, sedangkan menurut hasil penelitian Tambing et al. (2000), abnormalitas pada semen segar kambing PE sebesar 9,57 $\pm 0,87 \%$. Persentase abnormalitas pada semen segar ini memenuhi syarat semen yang layak untuk dilakukan proses selanjutnya dan baik untuk inseminasi buatan. Hal ini sesuai dengan pernyataan Toelihere (1993) bahwa abnormalitas pada semen kurang dari $20 \%$, masih layak digunakan untuk inseminasi buatan.

\section{Pengaruh Level Glutathione terhadap Kualitas Post-Thawing}

Kualitas semen kambing PE postthawing setelah penambahan glutathione dengan level berbeda diperlihatkan pada Tabel 2. Berdasarkan hasil analisis ragam menunjukkan bahwa level glutathione dalam pengencer tris-kuning telur berpengaruh nyata $(\mathrm{P}<0,05)$ terhadap motilitas sperma kambing $\mathrm{PE}$ post thawing. Motilitas pada kelima kelompok dengan penambahan glutathione dalam pengencer tris-kuning telur lebih tinggi dibandingkan dengan perlakuan tanpa penambahan glutathione (P0). Hal ini disebabkan pengencer tanpa glutathione hanya mendapat perlindungan dari gliserol. Gliserol merupakan krioprotektan intraseluler yang 
berfungsi untuk melindungi sperma akibat pembentukan kristal es saat proses pembekuan (Gazali \& Tambing, 2002). Penambahan gliserol tidak dapat mengurangi kerusakan membran plasma akibat peroksidasi lipid.

Hasil uji lanjut Duncan menunjukkan bahwa motilitas hasil perlakuan level glutathione $8 \mathrm{mM}$ nyata lebih tinggi $(\mathrm{P}<0,05)$ dibandingkan dengan $0 \mathrm{mM}, 4 \mathrm{mM}$, dan 10 $\mathrm{mM}$, namun tidak berbeda nyata dengan $6 \mathrm{mM}$. Pada level $6 \mathrm{mM}$ dan $8 \mathrm{mM}$ glutathione menghasilkan persentase motilitas yang cukup baik serta memenuhi syarat layak IB yaitu $43,82 \pm 4,07 \%$ dan $46,83 \pm 3,58 \%$. Hal ini sesuai dengan pernyataan Toelihere (1993) bahwa semen beku yang layak digunakan untuk progam IB memiliki persentase motilitas minimal 40\%. Penggunaan level $8 \mathrm{mM}$ glutathione memiliki kemampuan lebih baik dalam mempertahankan motilitas selama proses pembekuan. Hal ini sesuai dengan hasil penelitian Mishra et al. (2010) bahwa penambahan glutathione sebanyak $8 \mathrm{mM}$ pada semen kambing black bengal dalam pengencer tris dapat mempertahankan motilitas spermatozoa sebanyak 50\% selama 4 hari. Amalia et al. (2013) menyatakan bahwa, penggunaan level $6 \mathrm{mM}$ glutathione pada semen kambing boer memberikan hasil terbaik mencapai $29,5 \%$ dibandingan dengan penggunaan level $13 \mathrm{mM}$ dan $19 \mathrm{mM}$ glutathione.

Hasil penelitian juga menunjukkan bahwa terjadi penurunan motilitas pada level glutathione $4 \mathrm{mM}$ pada sperma kambing PE. Hal ini terjadi karena penambahan glutathione yang kurang optimal dapat mengakibatkan kurang efektifnya pengaruh glutathione dalam mempertahankan motilitas sperma. Hal ini sesuai dengan pernyataan Uysal \& Bucak (2007) bahwa terjadi penurunan motilitas pada perlakua konsentrasi $5 \mathrm{mM}$ disebabkan karena konsentrasi antioksidan belum mampu mencegah timbulnya radikal bebas dan memutus rantai peroksidasi lipid sehingga masih terjadi reaksi rantai peroksidasi lipid. Dibutuhkan keseimbangan antara antioksidan dan radikal bebas (prooksidan) dalam metabolisme sel, keseimbangan dapat berubah akibat adanya radikal bebas yang berlebihan.

Penurunan motilitas terjadi pula pada perlakuan level glutathione $10 \mathrm{mM}$ (Tabel 2). Hal ini terjadi akibat pemberian glutathione yang berlebihan yang menimbulkan efek toksik bagi sperma. Hasil penelitian Fitrianti et al. (2012) menyatakan bahwa motilitas spermatozoa pada semen kambing Boer dengan level $19 \mathrm{mM}$ glutathione $(19,75 \%)$ lebih rendah dibandingkan dengan level $6 \mathrm{mM}$ glutathione (20,25\%), disebabkan pemberian glutathione dalam jumlah banyak dapat menimbulkan toksik. Menurut Rizal dan Herdis (2010); Uysal \& Bucak (2007), penggunaan glutathione yang tidak sesuai akan berdampak negatif, tingginya konsentrasi glutathione dapat menimbulkan efek toksik pada spermatozoa, namun dengan menurunnya konsentrasi glutathione dalam plasma semen akan menyebabkan kurang efektifnya pengaruh glutathione terhadap spermatozoa.

Kerusakan kimiawi akibat radikal bebas hasil metabolisme pada sel sperma terjadi selama proses pembekuan. Proses metabolisme pada spermatozoa terus berlangsung selama proses pengenceran, ekuilibrasi, pembekuan hingga thawing. Peningkatan laju metabolisme dapat disebabkan adanya peningkatan temperatur, pada suhu rendah laju metabolisme suatu sel akan turun secara drastis sehigga dapat mempertahankan daya tahan sperma. Proses metabolisme pada sel sperma dapat menyebabkan terbentuknya hidrogen peroksida $\left(\mathrm{H}_{2} \mathrm{O}_{2}\right)$ yang dapat terdegradasi dan menghasilkan radikal hidroksil.

Tabel 2. Kualitas post-thawing semen kambing peranakan etawah setelah perlakuan level glutathione

\begin{tabular}{lccccc}
\hline \multirow{2}{*}{ Parameter } & \multicolumn{4}{c}{ Level Glutathione $(\mathrm{mM})$} \\
\cline { 2 - 5 } & $0(\mathrm{P} 0)$ & $4(\mathrm{P} 1)$ & $6(\mathrm{P} 2)$ & $8(\mathrm{P} 3)$ & $10(\mathrm{P} 4)$ \\
\hline Motilitas (\%) & $32,39+2,67^{\mathrm{a}}$ & $38,59+2,26^{\mathrm{b}}$ & $44,22+0,53^{\mathrm{c}}$ & $46,55+1,12^{\mathrm{c}}$ & $36,09+3,22^{\mathrm{b}}$ \\
Abnormalitas (\%) & $3,19+0,46^{\mathrm{a}}$ & $2,75+0,31^{\mathrm{a}}$ & $2,60+0,45^{\mathrm{a}}$ & $2,45+0,51^{\mathrm{a}}$ & $2,50+0,53^{\mathrm{a}}$ \\
Membran Plasma Utuh & $55,31+2,63^{\mathrm{a}}$ & $59,05+3,08^{\mathrm{ab}}$ & $54,79+9,60^{\mathrm{a}}$ & $66,45+2,37^{\mathrm{b}}$ & $57,90+2,73^{\mathrm{a}}$ \\
& & & & \\
(MPU) (\%) & & & & \\
Tudung Akrosom Utuh & $45,13+1,68^{\mathrm{a}}$ & $52,45+5,14^{\mathrm{b}}$ & $57,15+4,20^{\mathrm{bc}}$ & $59,60+4,92^{\mathrm{c}}$ & $53,15+5,92^{\mathrm{b}}$ \\
(TAU) (\%) & & & & \\
\hline
\end{tabular}

Keterangan: huruf superskrif yang berbeda pada baris yang sama menunjukkan berbeda nyata $(\mathrm{P}<0,05)$ 
Gunawan et al. (2012) menyatakan bahwa selama peroses pembekuan terjadi kerusakan spermatozoa yang dapat disebabkan oleh pembentukan kristal es, maupun kerusakan struktur membran akibat peroksidasi lipid. Kerusakan membran akibat peroksidasi lipid dapat terjadi pada saat proses thawing, dengan adanya peningkatan suhu yang sangat ekstrim, dan semen kontak dengan oksigen menyebabkan metabolisme dan konsentrasi radikal bebas meningkat. Peroksidasi lipid terjadi akibat adanya reaksi antara senyawa oksigen reaktif (ROS) dengan asam lemak tak jenuh ganda penyusun membran sel. Peroksidasi yang berkepanjangan dapat merusak struktur matrik lipid, dan menyebabkan instabilitas pada membran sel.

Kerusakan akibat peroksidasi lipid diantaranya merubah struktur spermatozoa, viskositas membran, dan penurunan motilitas (Feradis, 2010). Kerusakan membran plasma dapat mengakibatkan hilangnya motilitas karena hilangnya enzim-enzim yang dibutuhkan untuk metabolisme sel sehingga tidak dapat menghasilkan energi.

Glutathione merupakan antioksidan yang bekerja secara optimum pada tekanan oksigen tinggi, maka pada saat thawing, glutathione bekerja secara efektif dalam mencegah terjadi peroksidasi lipid yang dapat merusak membran plasma, yang akhirnya mempertahankan motilitas spermatozoa. Glutathione merupakan tripeptida (cystein, glutamine, dan glycin) yang berperan dalam melindungi sel dari kerusakan oksidatif yang disebabkan oleh ROS (Stradaioli et al, 2007).

Penambahan antioksidan dalam jumlah banyak akan semakin meningkatkan tekanan osmotik larutan pengencer, kerusakan membran plasma dan kurang dapat diadaptasi dengan baik oleh spermatozoa sehingga berakibat buruk terhadap berlangsungnya proses metabolisme spermatozoa. Selain itu, kandungan glutamat pada glutathione dapat mengikat lipoprotein dan lesitin pada kuning telur (Gunawan et al., 2012). Hal ini dapat menurunkan motilitas sperma karena proses metabolisme yang terganggu dapat mengakibatkan kurangnya produksi ATP yang digunakan spermatozoa untuk menghasilkan energi, sedangkan lipoprotein dan lesitin merupakan komponen kuning telur yang dapat melindungi sperma dari pengaruh cold shock.

Berdasarkan hasil analisis ragam menunjukkan bahwa level glutathione dalam pengencer tris-kuning telur tidak berpengaruh nyata terhadap persentase abnormalitas sperma kambing PE post thawing. Hal ini sesuai dengan hasil penelitian Amalia et al. (2013), bahwa penggunaan glutathione pada semen kambing tidak berpengaruh nyata terhadap abnormalitas sperma. Menurut Hartono (2008), semen kambing yang dibekukan masih memperlihatkan kualitas yang baik dan dapat digunakan untuk pelaksanaan IB apabila nilai abnormalitasnya berkisar 4,62-6,56\%. Seluruh perlakuan pada penelitian ini menghasilkan abnormalitas yang rendah yaitu berkisar antara $2,50 \pm 0,53 \%$ hingga $3,19 \pm 0,46 \%$.

Radikal bebas akan bereaksi dengan asam lemak tak jenuh penyusun membran plasma, sehingga dapat menyebabkan kerusakan membran plasma terutama pada bagian tengah spermatozoa tempat beradanya mitokondria. Hal ini dapat dicegah dengan penambahan glutathione dalam pengencer. Bagian tengah terdapat mitokondria yang terlibat dalam pembentukan energi untuk kehidupan dan pergerakan spermatozoa hasil metabolisme yang berlangsung dalam helix mitocondria. Abnormalitas pada bagian ekor dapat menghambat pergerakan dan fertilitas spermatozoa (Susmiarsih, 2010).

Berdasarkan Tabel 2 menunjukkan bahwa perlakuan level glutathion berpengaruh nyata $(\mathrm{P}<0,05)$ terhadap tudung akrosom utuh (TAU). Pada pengencer tanpa glutathione $\left(\mathrm{P}_{0}\right)$ menghasilkan nilai persentase TAU paling rendah, yaitu sebesar 45,8\%. Hal ini terjadi karena tidak adanya penambahan glutathione sehingga tidak ada antioksidan yang melindungi membran plasma dari serangan radikal bebas menyebabkan terjadinya reaksi peroksidasi lipid yang dapat merusak tudung akrosom. Daghigh-Kia et al. (2014) melaporkan bahwa penambahan glutathione memiliki pengaruh yang terbatas terhadap kualitas sperma dibandingkan dengan kontrol, dimana antioksidan tersebut meningkatkan viabilitas, integritas membran dan aktivitas glutathione peroksidase, namun hanya memiliki sedikit efek perlindungan terhadap pemeliharaan lipid peroksidase di dalam sel sperma post-thawing. Slaweta \& Laskowska (1987) serta Sinha et al. (1996) menyatakan bahwa antioksidan (glutathione) memainkan peran aktif dalam fruktolisis sperma, yang mungkin bertanggungjawab untuk meningkatkan aktivitas metabolik dan motilitas sperma. Selanjutnya dilaporkan bahwa terjadi penurunan konsentrasi aspartat aminotransferase, alanin aminotransferase dan laktat dehidrogenase pada semen beku sapi dan kambing yang ditambahkan $2 \mathrm{mM}$ dan $5 \mathrm{mM}$ glutathione dibandingkan dengan tanpa penambahan glutathione (kontrol), dimana semuanya merupakan enzim-enzim yang keluar 
dari kepala sel sperma akibat rusaknya akrosom. Hal ini menunjukkan bahwa glutathione dapat mencegah kerusakan akrosom.

Pada level $4 \mathrm{mM}$ glutathione menghasilkan nilai TAU lebih rendah yaitu sebesar $52,45 \%$ dibandingkan dengan nilai TAU pada level glutathione $6 \mathrm{mM}$ dan $8 \mathrm{mM}$ berturut-turut sebesar $57,15 \%$ dan $59,60 \%$. Hal ini terjadi karena adanya ketidakseimbangan antara jumlah spermatozoa yang terlindungi oleh glutathione dengan jumlah radikal bebas yang ada. Pendapat ini didukung oleh pernyataan Syarifuddin (2012) bahwa level glutathione yang kurang sesuai mengakibatkan peningkatan ROS yang dapat menyebabkan kematian sel spermatozoa. Salmani et al. (2013) melaporkan bahwa level $5 \mathrm{mM}$ glutathione efektif dalam menahan pembentukan malondialdehyde (MDA) dibandingkan dengan level $10 \mathrm{mM}$ glutathione ataupun tanpa perlakuan glutathione.

Level glutathione $8 \mathrm{mM}$ merupakan level dengan hasil TAU tertinggi sebesar 59,6\% dan menjadi batas level dalam mempertahankan TAU, hal ini terjadi karena adanya keseimbangan antara reaksi pengikatan radikal bebas oleh glutathione. Glutathione mampu menangkal radikal bebas yang sangat reaktif, dimana radikal tersebut dapat merusak senyawa penting untuk mempertahankan integritas sel, yaitu protein yang berupa enzimenzim yang terdapat di dalam akrosom untuk membantu proses fertilisasi. Keutuhan tudung akrosom dipengaruhi oleh keutuhan membran plasma yang akan melindungi vesikel akrosom tepat berada di bawah membran plasma sel di bagian ujung kepala spermatozoa dari kerusakan mekanik, karena spermatozoa yang memiliki membran plasma utuh mampu dengan baik mengatur lalu lintas keluar masuk semua substrat dan elektrolit pada tingkat sel, sehingga proses metabolisme dapat berlangsung dengan baik. Proses metabolisme ini menghasilkan adenosin triphospat (ATP) yang mengandung energi sehingga TAU dapat dipertahankan (Rizal et al., 2002).

Peningkatan level $10 \mathrm{mM}$ glutathione memberikan pengaruh negatif terhadap TAU, yaitu menyebabkan penurunan TAU menjadi sebesar $53,15 \%$. Hal ini terjadi karena terlalu tingginya level glutathione menyebabkan glutathione tidak efektif lagi bekerja sebagai antioksidan, bahkan menjadi suatu prooksidan (radikal bebas) yang justru memperbanyak terbentuknya radikal bebas. Beberapa peneliti melaporkan bahwa konsentrasi tinggi glutathione dapat menyebabkan degradasi DNA mitokondria (Whitaker et al., 2008), merusak integritas fungsional membrane dan akrosom sperma yang dikaitkan dengan motilitas (Atessahin et al., 2008; Zhang et al., 2015). Salmani et al., (2013) menyatakan bahwa efek pengrusakan konsentrasi tinggi glutathione terhadap motilitas mungkin berkaitan dengan kerusakan mitokondria dan axosome, penambahan glutathione $10 \mathrm{mM}$ nyata menurunkan viabilitas dan integritas membrane sperma. Nilai TAU pada penelitian ini lebih besar dari 30\% sehingga dapat diaplikasikan dalam program IB, sesuai dengan pendapat Evans \& Maxwell (1987) bahwa semen beku yang layak digunakan dalam program IB harus memiliki persentase TAU minimal $30 \%$.

\section{KESIMPULAN}

Berdasarkan hasil penelitian dan pembahasan disimpulkan bahwa level glutathione berpengaruh terhadap kualitas semen kambing Peranakan Etawah post-thawing dan level glutathione sebesar $8 \mathrm{mM}$ memberikan kualitas yang terbaik dan memenuhi standar kualitas inseminasi buatan (IB).

\section{UCAPAN TERIMA KASIH}

Penelitian ini terlaksana atas dukungan Hibah Internal UNPAD yaitu Academic Leadership Grant Laboratorium Reproduksi Ternak dan Inseminasi Buatan.

\section{DAFTAR PUSTAKA}

Amalia, F.R, Suyadi, \& A. Rachmawati. 2013. Pengaruh glutathione terhadap kualitas semen kambing boer post thawing dalam pengencer yang mengandung dimetylsulfoxide (DSMO). Universitas Brawijaya. Malang.

Atessahin, A., M.N. Bucak, P.B. Tuncer, \& M Kizil. 2008. Effects of antioxidant additives on microscopic and oxidative parame- ters of Angora goat semen following the freezethawing process. Small Ruminant Research 77:38-44.

Daghigh-Kia H, R. Olfati-Karaji, A. Hoseinkhani \& I. Ashrafi. 2014. Effect of rosemary (Rosmarinus officinalis) extracts and glutathione antioxidants on bull semen quality after cryopreservation. Span J of Agric Res 12(1):98-105.

Evans, G. \& W.M.C. Maxwell. 1987. Salamon's Artificial Insemination of Sheep and Goats. Butterworths. London. 
Feradis, M.P. 2010. Bioteknologi Reproduksi Pada Ternak. Alfabeta. Bandung.

Fitrianti, I.N., A. Rachmawati, \& Suyadi. 2012. Pengaruh Glutathione dalam Pengencer Tris Aminomethane Kuning Telur-Glycerol terhadap Kualitas Semen Kambing Boer setelah Pembekuan Cepat. Universitas Brawijaya. Malang.

Gazali, M. \& S.N. Tambing. 2002. Kriopreservasi Sel Spermatozoa. Hayati 9(1):27-32.

Gunawan I., D.N.D.I. Laksmi, \& I.G.N.B. Trilaksana. 2012. Efektivitas penambahan b-karoten dan glutathione pada bahan pengencer terhadap motilitas dan daya hidup spermatozoa pada semen beku sapi. Indonesia Medicus Veterinus 1(3):385-393.

Hartono, M. 2008. Optimalisasi penambahan vitamin $\mathrm{E}$ dalam pengencer sitrat kuning telur untuk mempertahankan kualitas semen kambing boer. J Indon Trop Anim Agric 33(1):11-19.

Hastono, U. Adiati, \& L. Praharani. 2013. Libido kemampuan kawin dan kualitas sperma kambing dari tiga bangsa. Prosiding Seminar Nasional Teknologi Peternakan dan Veteriner. Pusat Penelitian dan Pengembangan Peternakan. Bogor. Medan, 3-5 September 2013. Hlm 345 348.

Heriyanta, E., M.N. Ihsan, \& N. Isnaini. 2013. Pengaruh umur kambing peranakan etawah (pe) terhadap kualitas semen segar. J Ternak Tropika 14(2):1-5.

Holt, W.V. 2000. Basic aspects of frozen storage of semen. Anim Reprod Sci 62:3-22.

Lenzi, A., L. Gandini, F. Lombardo, M. Picardo, V. Maresca, E. Panfili, F. Tramer, C. Boitani, \& F. Dondero. 2002. Polyunsaturated fatty acids of germ cell membranes, glutathione and glutathione- dependent enzyme-PHGPx: from basic to clinic. Contraception 65:301-304.

Mishra, B., M.G.S. Alam, M.A.M.Y. Khandokar, S. Mazumder, \& M.N. Munsi. 2010. Qualities of goat semen in tris-citrateglucose extender containing glutathione. The Bangladesh Veterinarian 27(2):46-55.
Rizal, M. \& Herdis. 2010. Peranan antioksidan dalam meningkatkan kualitas semen beku. Wartazoa 20(3):139-145.

Rizal, M., M.R. Toelihere, T.L. Yusuf, B. Purwantara, \& P. Situmorang. 2002. Efektivitas berbagai konsentrasi glutation terhadap kualitas semen yang telah dibekukan pada domba garut. J Biosains 7: 22-28.

Salmani, H., M.H. Nabi, H. Vaseghi-Dodaran, M.B. Rahman, A. MohammadiSangcheshmeh, S. Shakeri, A. Towhidi, A.Z. Shahneh, \& M. Zhandi. 2013. Effect of glutathione in soybean lecithin-based semen extender on goat semen quality after freezethawing. Small Ruminant Research 112:123-127.

Sianturi, R.G., B. Purwantara, I. Supriatna, Amrozi, \& P. Situmorang. 2012. Pengaruh glutation dan penggantian plasma semen kerbau dengan plasma semen sapi terhadap kualitas semen beku kerbau Rawa (Bubalus bubalis). JITV 17(3):169-178.

Sinha, M.P., A.K. Sinha, B.K. Singh, \& R.L. Prasad. 1996. The effect of glutathione on the motility, enzyme leakage and fertility of goat semen. Anim Reprod Sci 41:237-243.

Slaweta, R. \& T. Laskowska. 1987. The effect of glutathione on the motility and fertility of frozen bull sperm. Anim Reprod Sci 13:249-253.

Solihati, N., S.D. $\quad$ Rasad, R. Setiawan, E.N. Foziah, \& E.T. Wigiyanti. 2018. Semen quality of post-thawed local ram's in tris-egg yolk extender with different glutathione level. IOP Conference Series Vol 119.

Stradaioli, G., T. Noro, L. Sylla, \& M. Monaci. 2007. Decrease in glutathione (GSH) content in bovine sperm after cryopreservation: comparison between two extenders. Theriogenology 67:1249-55.

Suryohudoyo, P. 2000. Oksidan, antioksidan, dan radikal bebas. Dalam: Kapita Selekta Ilmu Kedokteran Molekuler. Sagung Seto, Jakarta.

Susmiarsih, T. 2010. Peran genetik DNA mitokondria (mtDNA) pada motilitas spermatozoa. Majalah Kesehatan PharmaMedika 2(2):178-184. 
Suyadi, T.E., Susilorini, \& L. Amalta. 2015. Kualitas Semen Kambing Peranakan Etawah dalam Pengencer dengan Penambahan Ekstrak Bawang Merah (Allium cepa $\mathrm{L}$ ) selama Penyimpanan Suhu Dingin. Fakultas Peternakan Universitas Brawijaya. Malang.

Syarifuddin, A., D.N.D.I. Laksmi, \& I.W. Bebas. 2017. Efektivitas Penambahan berbagai Konsentrasi Glutathion terhadap Daya Hidup dan Motilitas Spermatozoa Sapi Bali Post Thawing. Indonesia Medicus Veterinus 1(2):176-185.

Tambing, S.N., M.R. Toelihere, T.L. Yusuf, \& I. K. Sutama. 2000. Pengaruh gliserol dalam pengencer tris terhadap kualitas semen beku kambing peranakan etawah. Jurnal Ilmu Ternak dan Veteriner 5(2).
Uysal, O. \& M. N. Bucak. 2007. Effects of oxidized glutathione, bovine serum albumin, cysteine and lycopene on the Quality of frozen-thawed ram semen. Acta Vet Brn. 76:383-390.

Whitaker, B.D. B. Carle, T. Mukai, A. Simpson, L. Vu, \& J.W. Knight. Effect of exogenous glutathione supplementation on motility, viability, and DNA integrity of frozen-thawed boar semen. Anim Reprod 5(3):127-131.

Zhang, X.G., G.J. Yan, J.Y. Hong, Z.Z. Su, G.S.,Yang, \& Q.W. Li. 2015. Effects of bovine serum albumin on boar sperm quality during liquid storage at $17^{\circ} \mathrm{C}$. Reproduction in Domestic Animals 50:263269. 